\title{
ANALISIS BUKU TEKS SISWA MATA PELAJARAN FIKIH DALAM PERSPEKTIF
} KEBUTUHAN PSIKOLOGI

\section{Oleh}

Abdul Kadir Ahmad

Kementerian Agama RI

Email: abduladir76@gmail.com

\section{Article History:}

Received: 14-10-2021

Revised: 15-11-2021

Accepted: 20-11-2021

\section{Keywords:}

Analisis Kesesuaian Isi, Buku Teks Fikhi, Tugas, Perkembangan Siswa
Abstract: Tercapainya tugas-tugas perkembangan peserta didik merupakan kebutuhan mutlak yang harus terpenuhi. Namun terkadang proses pembelajaran yang ia dapat di madrasah tidak membantunya mencapai tugas perkembangannya, akibatnya, mereka menjadi malas, bosan, bahkan tidak menyukai suatu mata pelajaran. Salah satu penyebabnya adalah pemilihan materi yang kurang sesuai dengan perkembangan psikologi peserta didik. Oleh karena itu. Penelitian ini dilakukan untuk menentukan kesesuaian isi dari materi yang tersaji dalam buku teks fikih Kelas XI terbitan kementerian agama dengan tugas perkembangan siswa pada aspek afektif. Penelitian ini menggunakan jenis penelitian kepustakaan (library research) dengan pendekatan kualitatif dimana teknik pengumpulan data yang digunakan adalah dokumentasi. Dalam menganalisis data, peneliti menggunakan teknik analisis isi atau conten analysis yaitu memberikan penafsiran terhadap data-data yang telah dikumpulkan dan mendapatkan kesimpulan dari penjabaran hasil analisis yang telah diakukan. Hasil penelitian ini menunjukkan bahwa jika dilihat dari jumlah tugas perkembangan yang sesuai pada masing-masing bab, maka ada dua bab yang sangat sesuai dengan tugas-tugas perkembangan afektifyaitu bab kelima dan keenam. Sebaliknya, materi atau bab yang tergolong sedang ada lima bab, dan tidak ada bab yang kategori kurang sesuai dengan tugas-tugas perkembangan. Jika dilihat dari jumlah bab yang sesuai pada masing-masing tugas perkembangan, terdapat tiga tugas yang sangat tinggi kesesuaiannya dengan materi, empat tugas yang tergolong rendah kesesuaiannya dengan materi yang tersaji pada buku. Sedangkan tugas lainnya, masuk kategori sedang. 
JCI

Jurnal Cakrawala Ilmiah

Vol.1, No.3, November 2021

\section{PENDAHULUAN}

Pendidikan agama saat ini menuai berbagai kritik yang tajam karena ketidakmampuannya dalam menanggulangi berbagai isu penting dalam kehidupan masyarakat, seperti mempercayai kepercayaan keagamaan dan keragaman kultural yang beraneka ragam yang sering melahirkan ketidakharmonisan dan konflik berbau SARA (suku, agama, ras, dan antar golongan). Sejumlah persoalan tersebut terkait dengan penyelenggaraan pendidikan agama di lapangan, sehingga peran keefektifannya dipertanyakan. disamping itu, pendidikan agama di madrasah atau sekolah juga dipandang belum mampu menjadi roh atau semangat yang mendorong pertumbuhan harmoni kehidupan sehari-hari. Hal ini tidak bisa dilepaskan dari kurikulum di Indonesia belum bisa menjawab persoalan tersebut. Landasan perencanaan kurikulum minimal mencakup tiga hal, yaitu: 1). Tuntutan sosial. 2). Perkembangan peserta didik. 3). Dan perbedaan gaya belajar siswa. (Ahmadi, 2013)

Pendidikan Islam juga mengakui bahwa faktor sosiologis selalu menjadi aspek terpenting dalam menyusun kurikulum. Dalam sebuah bukunya, Muzayyin Arifin menyatakan bahwa idealnya, Pendidikan Islam memang memiliki ruang lingkup yang berubah-ubah menurut waktu yang berbeda-beda dan bersikap lentur terhadap perkembangan kebutuhan umat manusia dari waktu ke waktu. (Arifin, M. 2011) Dan aspek sosiologis yang sangat dinamis tersebut ternyata berpengaruh besar pada aspek psikologis. Karena pada dasarnya, kondisi psikologis seseorang juga bergantung pada kondisi sosial budaya di mana ia tinggal. Kedewasaan anak-anak Indonesia bisa dikatakan lebih lambat jika dibandingkan dengan anak-anak Amerika. Anak-anak Amerika lebih cepat mandiri jika dibandingkan dengan anak-anak Indonesia. Hal ini disebabkan karena kultur budaya Indonesia yang memberi kesempatan pada anak-anaknya untuk tetap bergantung pada orang tuanya dalam waktu yang cukup lama

Baik faktor sosiologis, psikologis, maupun faktor lainnya, semuanya harus mendapat perhatian yang sama. Jika ada salah satu rambu yang diabaikan atau bahkan dilanggar maka kurikulum yang disusun tidak akan mampu mewujudkan tujuan pendidikan. Ketidaktepatan perumusan kurikulum pada akhirnya hanya akan menimbulkan berbagai masalah pendidikan yang bisa menjalari seluruh komponen kurikulum. Akhirnya pihak yang paling dirugikan adalah masyarakat atau lebih spesifiknya peserta didik sebagai penerima layanan pendidikan.

Kondisi anak atau peserta didik dapat kita pahami dengan mengetahui tahap perkembangan manusia. Setiap rentang usia atau fase perkembangan anak, memiliki ciri khas yang menuntut para pendidik untuk memberikan pengajaran atau bahan ajar yang juga sesuai dengan usia mereka. (Tohirin, 2005). Tugas-tugas perkembangan adalah tugas yang muncul pada saat atau sekitar suatu periode tertentu dalam kehidupan tertentu pada kehidupan individu, yang jika berhasil akan menimbulkan rasa bahagia dan membawa ke arah keberhasilan dalam melaksanakan tugas-tugas berikutnya. Dan jika gagal maka menimbulkan rasa tidak bahagia dan kesulitan dalam menghadapi tugas-tugas berikutnya. (Jannah, M. 2016)

Oleh karena itu, tercapainya tugas-tugas perkembangan peserta didik merupakan kebutuhan mereka yang mutlak harus terpenuhi. Jika proses pembelajaran yang ia dapat di madrasah tidak membantunya memenuhi kebutuhan dalam mencapai tugas 
perkembangannya, maka menjadi wajar jika mereka merasa malas, bosan, bahkan tidak menyukai suatu mata pelajaran. Berbeda jika peserta didik merasa materi yang diajarkan di madrasah/sekolah adalah sesuatu yang ia butuhkan, maka dari perasaan butuh itulah akan muncul sikap positif terhadap bidang itu sekaligus terhadap guru yang mengajarkannya. Motivasi dari dalam diri siswa yang mendorongnya untuk belajar, bisa muncul dari perasaan menyenangi materi yang diajarkan dan kebutuhannya terhadap materi tersebut, entah itu untuk kehidupan masa depannya atau untuk yang lain. (Tohirin, 2005). Dari penjelasan-penjelasan di atas, peneliti menemukan titik terang yang menguak fakta bahwa rasa tidak butuhlah yang menyebabkan peserta didik tidak menyukai mata pelajaran tertentu. Dan kebutuhan mereka dapat diketahui dari tugas-tugas perkembangan pada setiap fase perkembangan.

Yang menjadi salah satu pokok permasalahan pada Pendidikan Islam adalah cara pandang yang sempit mengenai ruang lingkup materi pendidikan agama yang bersumber dari ajaran Islam terutama mengenai kajian teologis. Karna pembahasannya hanya berhenti pada persoalan ketuhanan yang bersifat mistis-antologis tidak berhubungan dengan realitas kehidupan. Seperti persoalan keimanan yang selalu diorientasikan pada upaya mempertahankan akidah. Jarang sekali keimanan dikaitkan dengan persoalan yang lebih bersifat kontekstual dan menjawab persoalan hidup manusia. Kepedulian pada kemiskinan, ketidakadilan, kekerasan, dekadensi moral, dianggap bukan bagian dari proses aktualisasi keimanan. (Zurqoni dan Mukhibat, 2013)

Jika saja materi yang diajarkan adalah materi yang sesuai dengan konteks sosial masyarakat maupun konteks perkembangan individu, maka materi tersebut akan lebih mudah ditanamkan pada benak siswa dan lebih mudah diterapkan dalam kehidupan siswa. Karena memang materi itulah yang ia butuhkan untuk menghadapi hidup. Jika permasalahan yang bersumber dari materi ajar dapat teridentifikasi dengan benar, untuk kemudian diperbaiki, maka besar kemungkinan pendidikan di Indonesia akan mengalami kemajuan yang signifikan dan berpengaruh secara masif karena penetapan kurikulum bersifat terpusat dan terorganisir oleh kementerian yang berwenang. (Prahara, E. Y. 2009)

Materi ajar pada buku yang menjadi sumber ajar juga merupakan salah satu kunci sukses yang menentukan keberhasilan implementasi kurikulum. (Handayani, R. A, 2013) Namun dari beberapa perubahan dan penyempurnaan penyusunan materi ajar yang diterapkan pada kurikulum terbaru yaitu kurikulum 2013, ternyata masih ditemukan beberapa kekurangan, khususnya untuk buku yang ajar yang diterbitkan secara masif dan dalam pengawasan kemenag maupun kemendikbud.

Persoalan minat dan daya tarik siswa pada mata pelajaran Pendidikan Agama Islam adalah salah satu masalah yang membuka lebar pintu menuju permasalahan yang lebih besar yaitu gagalnya Pendidikan Islam dalam mengatasi mewabahnya dekadensi moral yang menjangkiti semua kalangan. Dari anak-anak, remaja, hingga orang dewasa, kini telah kehilangan pegangan dan terus terseret arus kemajuan zaman yang materialistis dan hampa dengan nilai-nilai luhur yang dulu dijunjung tinggi. Remaja merupakan kelompok usia yang paling rentan terjerumus dalam berbagai jurang amoral seperti penyimpangan perilaku seksual, penyalahgunaan obatobatan terlarang, dan tindak kriminal lainnya (Kadir \& Rahayu, 2020; Prastowo, A. 2015).

Berawal dari kegelisahan-kegelisahan tersebut, peneliti mencoba menganalisis kesesuaian materi atau bahan ajar yang ada pada buku teks pelajaran PAI dengan 
JCI

Jurnal Cakrawala Ilmiah

Vol.1, No.3, November 2021

kebutuhan tugas-tugas perkembangan siswa. Karena materi ajar yang tersusun dalam buku teks pelajaran merupakan sumber pembelajaran yang utama dan pertama. Meskipun peneliti tetap mengakui bahwa kemampuan guru dalam menyampaikan materi (metodologi) juga menjadi faktor penting. Namun tidak bisa dipungkiri bahwa setiap guru pasti mengacu pada bahan ajar atau materi yang telah tersaji pada buku. Materi yang akan peneliti analisis adalah materi mata pelajaran fikih kelas XII karena usia tersebut berada pada fase remaja akhir menuju dewasa awal sekaligus fase di mana peserta didik harus menghadapi beban dan pilihan-pilihan masa depan yang lebih sulit dibanding sebelumnya. Peran pendidikan sangat besar untuk membantu siswa mencapai tugas-tugas perkembangan nya. Dalam proses pembelajaran, ada tiga domain yang dijadikan sasaran yaitu kognitif, afektif dan psikomotor. Dan domain afektif merupakan domain yang membawahi dimensi-dimensi krusial dalam tugas-tugas perkembangan manusia yaitu emosional, moral, sosial, dan spiritual. Dari sebelas tugas perkembangan pada remaja, sembilan diantaranya tergolong dalam dimensi afektif. Oleh karena itulah penelitian ini berfokus pada tugas perkembangan individu pada aspek afektif. Jadi tujuan penelitian ini adalah untuk kesesuaian materi fikih kelas XII dengan kebutuhan perkembangan siswa. Tugas perkembangan yang dimaksud peneliti dalam penelitian ini adalah segala tugas perkembangan remaja pada ranah afektif yang berkaitan dengan perkembangan emosional, moral, sosial, dan spiritual. Penelitian ini diharapkan dapat menguak lebih mendalam dan menyajikan informasi baru mengenai kesesuaian materi fikih kelas XII dengan kebutuhan perkembangan siswa sehingga masalah dalam pembelajaran PAI (khususnya Fikhi) dapat teratasi, dan tujuan pendidikan Islam dapat tercapai dengan baik.

\section{METODE PENELITIAN}

Peneliti ini menggunakan pendekatan kualitatif, karena lebih menekankan pada pengumpulan data yang bersifat kualitatif. Jenis penelitian yang digunakan yaitu penelitian kepustakaan yaitu telaah yang dilaksanakan untuk memecahkan suatu masalah yang berdasarkan pada penelaahan kritis dan mendalam terhadap bahan-bahan pustaka yang relevan. Dalam hal ini bahan-bahan pustaka itu diperlakukan sebagai sumber ide untuk menggali pemikiran atau gagasan baru, sebagai bahan dasar untuk melakukan deduksi dari pengetahuan yang telah ada, sehingga kerangka teori baru dapat dikembangkan atau sebagai dasar pemecahan masalah. (Sugiyono, 2015) Penelitian ini akan mengkaji dan menelaah buku teks mata pelajaran fikih terbitan kementerian Agama RI tahun 2019 untuk memperoleh sajian kesesuaian buku ajar dengan tugas perkembangan.

Sumber data dalam penelitian ini adalah buku teks siswa Mata Pelajaran fikih kelas XII kurikulum 2013 terbitan Kemenag tahun 2019. Buku tersebut selanjutnya akan dianalisis dengan menggunakan pedoman dokumentasi berupa buku-buku dan sumber tertulis lain yang memuat teori tugas perkembangan milik Havigurst. (Yusuf, S. 2012) Untuk mempermudah proses analisis kesesuaian dan penarikan kesimpulan, peneliti memadukan dua cara dokumentasi yaitu dengan menggunakan pedoman dokumentasi sekaligus check list. Jadi, peneliti membuat tabel yang berisi semua judul bab yang ada pada buku PAI dan menyandingkannya dengan pedoman dokumentasi, dalam hal ini berupa tugas-tugas perkembangan. 


\section{HASIL DAN PEMBAHASAN}

\section{A. Gambaran Umum Isi Buku}

Sesuai amanat kurikulum 2013, buku teks bagi siswa ini dirancang untuk mengembangkan kompetensi yang utuh antara pengetahuan, keterampilan, dan sikap. Pembelajaran dalam buku ini dibagi dalam kegiatan-kegiatan keagamaan yang harus dilakukan peserta didik dalam usaha memahami pengetahuan agamanya. Akan tetapi, tidak berhenti dengan pengetahuan agama sebagai hasil akhir. Pemahaman tersebut harus diaktualisasikan dalam tindakan nyata dan sikap keseharian yang sesuai dengan tuntutan agamanya, baik dalam bentuk ibadah ritual yang berhubungan dengan pencipta maupun ibadah yang mengatur hubungan antara sesama dalam sosial kemasyarakatan. Buku ini menjabarkan usaha minimal yang harus dilakukan peserta didik untuk mencapai kompetensi yang diharapkan.

Untuk menunjang tujuan pembelajaran yang telah ditetapkan, buku ini dilengkapi dengan komponen-komponen antara lain:

1. Peta konsep kompetensi dan materi yang akan dipelajarinya dalam bab tersebut. suatu bagan skematis atau ilustrasi grafis untuk mewakili hubungan yang bermakna antara satu konsep dengan konsep lainnya sehingga menjelaskan suatu pengertian konseptual seseorang dalam suatu rangkaian pernyataan. Peta konsep adalah suatu cara atau strategi untuk menyajikan informasi dalam bentuk konsep-konsep yang saling terhubung dalam suatu rangkaian.

2. Prawacana, yaitu kata pendahuluan dari materi yang dibahas dalam bab tersebut. Ini berfungsi mengantarkan pembaca kepada isi atau uraian-uraian yang terdapat di dalam suatu tulisan. Kata pengantar juga dilengkapi dengan uraian yang mendorong membangkitkan minat orang lain untuk membaca buku tersebut.

3. Pengamatan, yaitu menampilkan tulisan yang berkaitan atau sesuai dengan tema yang akan dipelajari untuk diamati agar menimbulkan rasa ingin tahu, lalu didiskusikan makna yang terkandung di dalam tulisan deskrisi tersebut.

4. Membuka hazanah peserta didik, yaitu peserta didik diberikan informasi/ materi/konsep untuk menambah wawasan keilmuan mereka sebagai acuan untuk melakukan perubahan sikap yang lebih baik.

5. Aktivitas Peserta didik, yaitu menampilkan tugas yang harus dikerjakan oleh peserta didik agar lebih memahami. Berisi problem solving ajakan berpikir yang berkaitan dengan tema yang sedang dipelajari. Tujuannya agar peserta didik dapat mengambil hikmah untuk kemudian dijadikan bahan instrospeksi diri

6. Tugas Mandiri, yang terdiri dari tugas terstruktur dan Tugas tidak terstruktur. Tujuan tugas struktur adalah tugas yang diberikan kepada siswa dalam rangka meningkatkan pemahamannya terhadap suatu materi pembelajaran dimana waktu pengumpulan ditentukan oleh guru biasanya ditentukan pada pertemuan berikutnya. Sedangkan tugas tidak terstruktur adalah tugas yang diberikan kepada siswa dalam jangka waktu yang cukup lama misalkan satu bulan atau bahkan satu semester.

7. Wawasan, berisi bukti-bukti realiatas kehidupan agar peserta didik dapat mengkritisinya terkait dengan tema dan mampu menerapkannya dalam kehidupan sehari-hari. berisi pengembangan materi untuk memfasilitasi peserta didik dalam menciptakan proses pembelajaran yang efektif. Sehingga peserta didik dapat menikmati pembelajaran dengan kreatif dan inovatif. 
JCI

Jurnal Cakrawala IImiah

Vol.1, No.3, November 2021

8. Rangkuman, berisi kesimpulan materi dari setiap bab

9. Uji Kompetensi, peserta didik diberikan penguatan pemahaman dengan berlatih mengerjakan soal-soal, berupa soal-soal pilihan ganda, isian, esai dan pilihan sikap untuk menguji pemahaman dan penerapan konsep

\section{B. Ruang Lingkup Aspek Afektif pada Tugas Perkembangan}

Ada tiga aspek perkembangan yang harus menjadi sasaran dalam proses pendidikan, yaitu aspek kognitif, afektif, dan psikomotor. Pada penelitian ini, peneliti hanya berfokus pada aspek afektif dan membahasnya secara mendalam dan detail untuk mengetahui batasan-batasan atau ruang lingkup kajian pada aspek afektif agar dapat diketahui apa saja tugas perkembangan yang termasuk dalam ranah afektif.

Untuk mengetahui apakah seorang remaja berhasil atau gagal dalam mencapai tugas tersebut, harus ada indikator-indikator pencapaian tugas berupa ciri-ciri perilaku yang nampak pada remaja. Mengutip pendapat dari Havigurst, Syamsu Yusuf telah memaparkan secara rinci kesembilan tugas tersebut beserta indikator keberhasilan pencapaian tugas yaitu sebagai sebagai berikut:

1. Mencapai hubungan yang lebih matang dengan teman sebaya. Hubungan remaja dengan teman sebayanya, tidak lagi seperti saat mereka masih anak-anak. Saat kanak-kanak, interaksi sosial dengan teman sebaya masih cenderung pada bermain bersama, bersenang-senang, dan terkadang mulai belajar bekerja sama. Namun, saat mereka beranjak remaja, interaksi tersebut akan berkembang menjadi lebih matang

2. Mencapai peran sosial sebagai pria atau wanita. Peran sosial ini biasa disebut sebagai peran gender. Sama halnya dengan anak yang harus mempelajari perannya sebagai anak terhadap orang tua atau sebagai murid terhadap guru, maka ia juga harus mempelajari perannya sebagai anak dari jenis kelamin tertentu. (Sarwono, S. W, 2011).

3. Mencapai kemandirian emosional dari orang tua dan orang dewasa lainnya. Hakikat pencapaian tugas ini adalah agar remaja dapat membebaskan diri dari sikap dan perilaku yang kekanak-kanakan atau bergantung pada orang tua. Selain itu juga untuk mengembangkan afeksi atau kasih sayang kepada orang tua tanpa bergantung kepadanya.

4. Mencapai jaminan kemandirian ekonomi. Setiap remaja ingin segera menjadi mandiri dalam segala hal termasuk kemandirian ekonomi, meski di usia masih madrasah/sekolah dan orang tua mereka masih bersedia menanggung semua biaya hidupnya, namun remaja mulai berpikir untuk mempersiapkan diri mengejar pekerjaan impian mereka

5. Memilih dan mempersiapkan karir. Masalah karir merupakan masalah yang menjadi perhatian khusus baik bagi remaja sendiri maupun orang tuanya. Remaja dengan perkembangan kognitifnya yang dapat memikirkan hal-hal bersifat abstrak seperti masa depan, sudah mulai menggali keinginan dan minat pekerjaan yang akan mereka pilih dan sesuai dengan kemampuan dan bakat mereka. namun masih banyak remaja, bahkan belum sampai pada tahap mengetahui kemampuan dan potensi dirinya.

6. Mempersiapkan pernikahan dan hidup berkeluarga. Seiring dengan perkembangan fisiknya yang sudah matang, remaja dituntut untuk mengembangkan sikap positif 
terhadap pernikahan, hidup berkeluarga, dan memilki anak serta memperoleh pengetahuan yang tepat tentang pengelolaan keluarga dan perawatan anak. Ketertarikan pada lawan jenis yang dialami remaja merupakan hal yang wajar dan alamiah karena kematangan organ seksualnya. Namun, hal ini perlu diarahkan agar tetap berada di jalur yang positif dan sesuai norma yang berlaku.

7. Mencapai tingkah laku yang bertanggung jawab secara sosial. Dualisme sikap orang dewasa yang bimbang antara memberi kesempatan atau tidak pada remaja untuk ikut berpartisipasi dalam kegiatan mereka, memberikan dampak buruk bagi perkembangan sosial remaja. Banyak remaja yang tidak mempunyai keterampilan sosial karena orang dewasa di sekitar mereka, masih menganggap mereka belum siap dan belum bisa melaksanakan tanggung jawab sosial layaknya orang dewasa. Sehingga, remaja yang mendapat perlakuan tersebut akan merasa terasingkan dari lingkungan sosialnya.

8. Memperoleh seperangkat nilai dan sistem etika sebagai petunjuk atau pembimbing dalam bertingkah laku. Hakikat tugas perkembangan ini ialah agar remaja mampu mengembangkan kesadaran untuk merealisasikan nilai-nilai yang dijunjung di masyarakat mereka, dan memahami gambaran hidup dan nilai-nilai yang dimilikinya, sehingga dapat hidup harmonis dengan orang lain. Nilai-nilai dapat mereka peroleh dari kehidupan keluarga.

9. Beriman dan bertaqwa kepada Tuhan Yang Maha Esa. Beriman dan bertaqwa kepada Tuhan Yang Maha Esa merupakan wujud dari perkembangan moral dan religi remaja. Sebagian orang berpendapat bahwa moral dan religi bisa mengendalikan tingkah laku anak yang beranjak dewasa atau remaja, sehingga ia tidak melakukan hal-hal yang bertentangan dengan kehendak atau pandangan masyarakat. Di sisi lain, tidak adanya moral dan religi sering dianggap sebagai faktor penyebab meningkatnya kenakalan remaja. Oleh karena itu, ketercapaian tugas ini sangatlah penting. (Yusuf, S. 2012)

Substansi dari tugas perkembangan ini adalah tercapainya kematangan sikap, kebiasaan dan pengembangan wawasan dalam mengamalkan nilai-nilai keimanan dan ketakwaan kepada Tuhan dalam kehidupan sehari-hari, baik pribadi maupun sosial. Menurut perspektif agama, remaja sebagai bagian dari siklus kehidupan manusia, merupakan masa "starting point" pemberlakuan hukum tasyri bagi seorang insani (mukallaf). Karena itulah, remaja seharusnya sudah melaksanakan nilai- nilai agama dalam kehidupannya. Sesuai dengan sabda Rasul Saw. yang artinya: "Pena (pencatat amal) itu diangkat untuk ketiga kategori manusia, yaitu jabang bayi sampai remaja, orang tidur sampai bangun, dan orang gila sampai sembuh kembali".

\section{Analisis Kesesuaian Materi fikih Kelas XI dengan Kebutuhan Tugas Perkembangan Remaja pada Aspek Afektif}

1. Kesesuaian Bab I. Jinayah dan Hikmahnya dengan Tugas Perkembangan

Setelah peneliti menganalisis materi pada bab ini dengan teknik analisis isi, dapat disimpulkan bahwa terdapat tiga tugas perkembangan yang sesuai dengan materi tentang meyakini hari akhir. Berikut penjabarannya dan disertai bukti berupa beberapa kutipan dari buku yang dianalisis

a. Mencapai tingkah laku yang bertanggung jawab secara sosial

Pernyataan-pernyataan pada bab pertama buku ini yang sesuai dengan tugas 
JCI

Jurnal Cakrawala Ilmiah

Vol.1, No.3, November 2021

mencapai tingkah laku yang bertanggung jawab secara sosial, diantaranya adalah pada bagian prawacana halaman 4 berikut: "hukum sebab akibat berlaku, siapa yang berbuat, maka ia harus bertanggung jawab, begitu pula dalam pidana Islam yang menjelaskan tanggung jawab pelaku pidana kejahatan harus menerima akibat hukumnya. ...."

Beberapa kalimat pernyataan tersebut, merupakan salah satu upaya penyusun buku untuk membangkitkan logika berpikir peserta didik tentang adanya pertanggungjawab atas perbuatan seseorang yang dikaitkan dengan prinsip kematangan bergaul dengan teman sebaya. Sehingga bersikap dewasa akan memunculkan sikap tanggung jawab secara sosial.

b. Memperoleh seperangkat nilai, etika dan menjadikannya prinsip hidup

Seperangkat nilai yang dapat diperoleh siswa pada bab ini untuk diterapkan pada kehidupan mereka yaitu nilai saling memelihara kehormatan dan keselamatan jiwa setiap manusia seperti yang telah dijelaskan pada halaman 9 bahwa hukuman bagi pelaku pembunuhan tidak lain untuk memelihara kehormatan dan keselamatan jiwa setiap manusia. Sehingga apabila hak alamiah manusia ini dirusak oleh orang lain, maka yang terjadi adalah ketidakharmonisan dalam kehidupan bermasyarakat.

Nilai lain yang diajarkan dalam buku ini tepatnya pada halaman 16 adalah senantiasa bersikap adil kepada siapapun. Demikian juga bagian Problem Solving di hal 25 yaitu nilai mengatasi suatu permasalahan. setip siswa diharuskan mempunyai solusi.

c. Beriman dan bertaqwa kepada Tuhan Yang Maha Esa

Pernyataan-pernyataan pada bab pertama buku ini yang sesuai dengan tugas perkembangan beriman dan bertakwa kepada Tuhan, diantaranya adalah pada halaman 24 bahwa hikmah kifarat bahwa manusia benar-benar menyesali perbuatan yang keliru, telah berbuat dosa kepada Allah dan merugikan sesama manusia. Lalu menuntun manusia agar segera bertaubat kepada Allah atas tindak maksiat yang ia lakukan. Serta menstabilkan mental manusia, hingga ia merasakan ketenangan diri karena tuntunan agama (membayar kifarat) telah ia tunaikan.

2. Kesesuaian Bab II Hudud Dan Hikmahnya dengan Tugas Perkembangan

Sama dengan bab pertama, pada bab ini hanya tiga poin tugas perkembangan yang terpenuhi dari total sembilan tugas perkembangan pada aspek afektif. Banyak materi pada bab ini yang sangat mendukung pencapaian tugas memperoleh seperangkat nilai, etika dan menjadikannya pedoman hidup. Berikut adalah analisis lebih detailnya

a. Beriman dan bertaqwa kepada Tuhan Yang Maha Esa.

Materi ini dapat meningkatan keimanan kepada Allah swt, karena dengan menghindari diri minuman khamar agar menjaga hati agar tetap bersih, jernih, dan dekat kepada Allah ta'ala. Seperti pada halaman 47 bahwa khamr akan mengganggu kestabilan jasmani dan rohani. Hati pecandu khamr hari demi hari akan semakin jauh dari Allah. Hatinya menjadi gelap, keras hingga ia tak sungkansungkan melakukan pelanggar terhadap aturan syar'i.

b. Mempersiapkan pernikahan dan hidup berkeluarga 
Materi pada bab ini dapat meningkatkan sikap dalam menyiapkan diri untuk memasuki fase kehidupan di dunia ini yaitu menikah dan hidup berkeluarga. Seperti yang dijelaskan pada halaman 42, yaitu beberapa hikmah disyariatkan pengharaman zina adalah: memelihara dan menjaga keturunan dengan baik, menjaga harga diri dan kehormatan manusia. Serta menjaga ketertiban dan keteraturan rumah tangga, dan memunculkan rasa kasih sayang terhadap anak yang dilahirkan dari pernikahan sah.

c. Memperoleh seperangkat nilai, etika dan menjadikannya prinsip hidup

Nilai yang dapat diajarkan pada peserta didik pada bab ini adalah seperti yang tercantum pada halaman 44, disitu dijelaskan bahwa di antara hikmah diharamkannya qadzab adalah menjaga kehormatan diri seseorang di mata masyarakat, tidak mudah melakukan kebohongan dengan cara menuduh orang lain berbuat zina, bersegera bertaubat apabila melakukan suatu kesalahan dengan merasa jera dan sadar dari perbuatannya yang tidak terpuji, serta menjaga keharmonisan pergaulan antar sesama anggota masyarakat, dan mewujudkan keadilan di kalangan masyarakat berdasarkan hukum yang benar. Demikian juga pada halaman 47 bahwa hikmah diharamkannya khamar (minuman keras) adalah mencegah kerusakan yang kerusakan yang disebabkan meminum khmar, sebab khamr merupakan induk segala macam bentuk kejahatan. Demikian juga untuk menjaga kesehatan jasmani dan rohonai dari berbagai penyakit. Pada halaman 51 juga menegaskan nilai hidup rajin dan menjauhi sikap malas dalam mencari rezeki.

3. Kesesuaian Bab III Bughat (Pemberontakan) dengan Tugas Perkembangan

Pada bab ini, materi yang disajikan hanya memenuhi dua poin tugas perkembangan remaja. Yaitu tugas beriman dan bertaqwa kepada Tuhan Yang Maha Esa dan tugas memperoleh seperangkat nilai, etika dan menjadikanya prinsip hidup. Berikut letak kesesuaiannya.

a. Memperoleh seperangkat nilai, etika dan menjadikannya prinsip hidup

Banyak nilai luhur yang ingin ditanamkan penyusun buku pada peserta didik. Nilai yang paling banyak ditampilkan adalah nilai keadilan, produktif, tanggung jawab, dan kerja keras. Seperti pada kutipan bagian prawacana halaman 61 sebagai berikut: "Fenomena ekonomi Islam, berkembang pula kepada produkproduk yang bersimbolkan agama seperti, hijab syar'i, wisata halal, hijrah di kalangan anak-anak muda dan berbagai keberagamaan lainnya. Satu sisi fenomena ini mengembirakan tetapi di sisi lain juga menyedihkan. Penguatan simbol-simbol Islam seharusnya diiringi dengan nilai-nilai akhlak yang luhur, terutama dalam hal kehidupan bertetangga, berbangsa dan bernegara."

b. Mencapai tingkah laku yang bertanggung jawab secara sosial

Pada halaman 63 telah ditulis banyak perilaku mulia yang dapat diimplementasikan untuk menerapkan sikap hidup bermasyarakat dengan mengingatkan seseorang yang melakukan sesuatu yang melanggar hukum, agar sadar atas kesalahan yang mereka lakukan, hingga akhirnya mau kembali taat kepada peraturan yang berlaku dan melaksanakan kewajiban mereka sebagai warga negara. Hal ini selaras dengan salah satu tugas perkembangan yang sangat krusial dalam perkembangan remaja, yaitu mencapai tingkah laku yang 
JCI

Jurnal Cakrawala Ilmiah

Vol.1, No.3, November 2021

bertanggung jawab secara sosial. Dengan sering mengajak atau mengingatkan teman maupun orang lain di lingkungannya, remaja sudah dikatakan sadar dengan tanggung jawabnya dalam bermasayarakat.

c. Beriman dan bertaqwa kepada Tuhan Yang Maha Esa

Dengan mengetahui bahwa Islam merupakan agama yang menebarkan kedamaian ke semua makhluk hidup, menghindari sesuatu yang bisa merusak atau merugikan orang lain, maka peserta didik akan merasa lebih bangga dengan agamanya dan keyakinannya tentang Islam sebagai agama yang penuh rahmat, akan semakin kuat. Cara-cara atau strategi menangani seseorang memberontak atau makar kepada pemerintah yang sah tersebut telah dijelaskan dengan baik pada buku tersebut pada halaman 70. Dan Jika pelaku bughat bertaubat, maka taubatnya diterima dan ia tidak boleh dibunuh.

4. Kesesuaian Bab IV Peradilan Islam dengan Tugas Perkembangan

a. Beriman dan bertaqwa kepada Tuhan Yang Maha Esa

Peserta didik diingatkan untuk bersikap adil kepada siapapun, karena itu akan mendekatkan diri kepada Allah swt. hal ini dampak pada halaman 74 yaitu "Banyaknya permasalahan atau sengketa diantara manusia, maka perlu adanya upaya menyelesaikan permasalahan tersebut yang seadil-adilnya. ...". Demikian juga pada halaman 76 bahwa ketenangan dalam hidup di dunia ini akan bisa membuat seseorang beribadah dengan tenang. Halaman 78 tentang ancaman neraka api seorang hakim yang memutuskan suatu perkara dengan tidak adil.

b. Memperoleh seperangkat nilai, etika dan menjadikannya prinsip hidup

Banyak nilai yang akan diperoleh siswa dalam bab ini, yang dapat dijadikan pegangan dalam hidupnya. Misalnya pada halaman 75 "mengaplikasikan nilainilai amar makruf nahi mungkar, dengan menyampaikan hak kepada siapapun yang berhak menerimanya dan menghalangi orang-orang zalim dari tindak aniaya yang akan mereka lakukan". Demikian nilai hidup bermasyarakat dengan terlibat dalam menciptakan ketertiban dan ketentraman masyarakat. Serta halaman 78 tentang sikap teliti dan cermat dalam memutuskan suatu perkara, terhindar dari sikap terburu-buru dalam mengambil suatu kesimpulan. Seorang hakim tidak diperbolehkan mengambil suatu kesimpulan dalam kondisi lapar, marah, sedih, dan sebagainya, sebab hal-hal tersebut dapat menyebabkan ijtihad hakim tidak maksimal.

c. Mencapai peran sosial sebagai pria atau wanita

Islam menekankan persamaan antara laki-laki dengan wanita, sebab keduanya sama-sama makhluk ciptaan Allah yang diberi akal sehat. Mereka sama dalam hal mendapatkan pahala dan siksaan dari Allah baik yang bersifat dunia maupun ukhrawi secara keseluruhan. Halaman 79 tentang kedudukan hakim wanita, dijelaskan bahwa ada ulama yang membolehkan pengangkatan hakim wanita untuk segala urusan seperti halnya hakim pria. Sebab ketika wanita dibolehkan memberikan fatwa dalam segala macam hal, maka ia juga mendapatkan keleluasaan untuk menjadi hakim dan memutuskan perkara apapun. Oleh karena itu hakim yang ada di Indonesia diperbolehkan bagi wanita. 
5. Kesesuaian Bab V Pernikahan dengan Tugas Perkembangan

a. Beriman dan bertaqwa kepada Tuhan Yang Maha Esa

Seperti bab-bab sebelumnya, bab ini juga sesuai dengan tugas perkembangan remaja yang pertama yaitu beriman dan bertaqwa pada Tuhan Yang Maha Esa. Keimanan seorang remaja kepada Allah akan bertambah karena mengetahui bahwa Allah mensyariatkan pernikahan kepada manusia untuk menjaga martabat dan kehormatan manusia, dan agar manusia terhindar dari penyakit kelamin. Tak hanya itu, pensyariatan pernikahan juga mengandung hikmah yang sangat memperhatikan masa depan bangsa. Karena dengan adanya pernikahan dan terbentuknya keluarga yang harmonis, maka keluarga tersebut akan berhasil melahirkan generasi penerus bangsa yang cemerlang, seperti yang telah dipaparkan pada halaman 94 - 95

b. Mencapai peran sosial sebagai pria dan wanita

Pada halaman 96 telah dijelaskan bahwa salah satu tujuan pernikahan adalah untuk memenuhi tuntutan naluri dasar manusia. Naluri yang dimaksud dalam pernyataan buku tersebut adalah naluri manusia untuk mulai berpasangan dengan lawan jenisnya dengan tanda-tanda psikologis berupa munculnya ketertarikan dengan lawan jenisnya. Hal itu terjadi pada saat manusia menginjak usia remaja, karena pada saat itu, perkembangan fisik remaja tepatnya perkembangan organ reproduksinya sudah mulai matang.

Penyajian materi pernikahan pada salah satu bab pada buku ini, merupakan hal yang sangat tepat karena akan mendukung pencapaian tugas remaja untuk mencapai peran sosialnya sebagai laki-laki dan wanita. Mereka akan menyadari bahwa kelak saat mereka dewasa, remaja laki-laki akan berperan sebagai suami, dan remaja putri akan berperan sebagai seorang istri.

c. Kemandirian emosional dari orang dewasa (melepas ketergantungan)

Adanya hak dan kewajiban suami dan istri mengharuskan remaja untuk belajar hidup mandiri sedini mungkin. Kewajiban dalam rumah tangga, yang biasa dilakukan oleh orang tua mereka, kini mereka mulai sadar bahwa tak lama lagi, mereka akan mempunyai kewajiban yang sama dan benar-benar lepas dari pengayoman kedua orang tua mereka. Pengetahuan tentang hak dan kewajiban suami istri yang terdapat pada halaman 120 akan membuat mereka mempersiapkan diri dan belajar untuk melakukan hal-hal yang dilakukan orang dewasa.

d. Mempersiapkan pernikahan dan hidup dan berkeluarga

Topik bahasan pada bab ini sangat sesuai dengan tugas perkembangan remaja untuk mempersiapkan pernikahan dan hidup dan berkeluarga. Pencapaian tugas ini dapat dilakukan dengan mengembangkan sikap positif remaja terhadap pernikahan, hidup berkeluarga, dan memilki anak serta memberikan mereka pengetahuan yang tepat tentang cara menyikapi perubahan kondisi fisiknya setelah pubertas. Berikut adalah beberapa poin materi yang dapat mendukung tercapainya tugas tersebut.

Pada halaman 94 dijelaskan bahwa alasan disyariatkannnya pernikahan dalam Islam adalah karena pernikahan merupakan fitrah manusia dan jalan paling mulia dalam mengendalikan mengendalikan hawa nafsu seks manusia. Selain itu, dalam 
salah satu ayat Alquran yaitu An-Nahl ayat 72, Allah jelas-jelas menerangkan bahwa Dia menciptakan segala sesuatu dengan berpasang-pasangan. Pada halaman selanjutnya, lebih ditegaskan lagi bahwa Rasulullah menganjurkan remaja yang sudah mampu, untuk segera menikah agar kondisi jiwanya lebih sehat.

e. Bertanggung jawab secara sosial (berpartisipasi dalam masyarakat) Keluarga sebagai anggota atau bagian dari masyarakat juga mempunyai peran yang sangat penting dalam membangun sebuah peradaban. Pada halaman 95 telah dijelaskan bahwa pasangan suami istri harus berusaha berperan aktif dalam berbakti pada lingkungan dan masyarakat, dengan begitu keluarga tersebut akan mendapatkan eksistensi dan peran yang penting di masyarakat. Remaja yang memahami peran keluarga dalam masyarakat, akan merasa bahwa mereka harus memulai peran serta mereka dalam masyarakat sedini mungkin agar kelak saat sudah berkeluarga dan dibebani tanggung jawab yang lebih besar di masyarakat, mereka tidak merasa amatir dan kaku dalam menjalin komunikasi dengan berbagai macam orang dengan watak yang berbeda-beda dalam masyarakat

f. Memperoleh seperangkat nilai, etika dan menjadikannya prinsip hidup

Pada halaman 96-97, pada bagian hukum pernikahan dan hikmah pernikahan pada halaman 120, diterangkan bahwa menikah merupakan cara Allah menjaga kehormatan manusia dari perbuatan zina. Prinsip menjaga kehormatan harus benar-benar dipegang dan oleh remaja. Karena banyak dari remaja zaman sekarang telah melakukan penyimpangan dalam berhubungan dengan lawan jenis. Pergaulan bebas tersebut sangat merugikan dirinya sendiri, bahkan merugikan bangsa dan negara. Karena anak yang lahir dari keluarga single parent akan rentan mengalami lack of love yang berakibat pada kurang optimalnya perkembangan anak. Semua akibat buruk dari pergaulan bebas dan seks bebas merupakan dampak dari pelanggaran nilai dalam menjaga kehormatan dirinya dan keturunannya.

g. Mencapai jaminan kemandirian ekonomi

Remaja yang tinggi pencapaiannya dalam tugas ini adalah mereka yang sudah mempersiapkan atau merencanakan kehidupan ekonomi mereka dengan matang dan melangkah secara pasti dalam usaha mencapai tujuan hidupnya yang berkaitan dengan kemapanan ekonomi. Pada tugas perkembangan ini, materi fikih hanya memberikan kontribusi dalam hal penanaman nilai dan kesadaran peserta didik yang dapat memotivasinya dalam mencapai tugas perkembangan ini.

Dalam usaha menyadarkan peserta didik akan adanya beban ekonomi yang akan mereka tanggung sendiri saat dewasa terutama saat sudah berkeluarga kelak, pada halaman 120 - 121 tentang kewajiban suami terhadap istri, peserta didik diberikan gambaran bahwa pria akan mengemban tugas dan tanggung jawab yang lebih berat dalam keluarga. Beban yang dimaksud di sini tentunya adalah beban nafkah yang harus mereka berikan pada keluarga mereka. Kesadaran akan masa depan tersebut, membuat remaja laki-laki lebih memikirkan karir dan kehidupan ekonominya dibanding dengan remaja putri. 
6. Kesesuaian Bab VI Perceraian dengan Tugas Perkembangan

a. Beriman dan bertaqwa kepada Tuhan Yang Maha Esa

Substansi dari tugas perkembangan ini adalah tercapainya kematangan sikap, kebiasaan dan pengembangan wawasan dalam mengamalkan nilai-nilai keimanan dan ketakwaan kepada Tuhan dalam kehidupan sehari-hari, baik pribadi maupun sosial. Dalam mencapai tugas tersebut, remaja memerlukan wawasan-wawasan keagamaan terutama yang menyangkut akidah dan keimanan. Kesesuaian bab ini dengan tugas perkembangan tersebut tidak lain adalah materi-materinya yang berorientasi pada kepatuhan pada perintah atau syariat yang ditetapkan Allah. Senantiasa berusaha yang terbaik, namun apapun hasilnya diserahkan sepenuhnya kepada Allah.

b. Mencapai tingkah laku yang bertanggung jawab secara sosial

Perceraian adalah sesuatu yang diperbolehkan dalam Islam, namun bukan berarti perceraian itu digunakan sesukanya pasangan suami istri. Justru dengan pasangan suami istri yang bercerai, terdapat dampak yang diakibatkan. Misalnya bagaimana kelanjutan anak keturunan dan bagaimana hubungan dengan keluarga yang diceraikan? Maka dalam Islam walaupun perceraian itu boleh namun perceraian itu menjadi solusi yang terakhir dalam penyelesaian persoalan. Ini ditegaskan dalam halaman 132. Dan pada halaman 138 tentang kewajiban suami ketika terjadi perceraian bahwa seorang suami yang mencerai istrinya tetap berkewajiban memberi belanja dan tempat tinggal hingga masa iddahnya berakhir.

c. Mencapai peran sosial sebagai lak-laki atau wanita Alquran telah memberikan porsi secara benar mengenai hak-hak kaum wanita. Selain itu, pedoman umat Islam ini juga membicarakan kesamaan antara wanita dan pria di hadapan Allah, khususnya dalam hal perolehan pahala dari amal-amal salehnya. Pada halaman 138 - 139 menegaskan suami dan istri masing-masing mempunyai hak dan kewajiban atas konsekwensi terjadi perceraian. Tidak boleh seorang suami atau istri berlepas diri dari hal tersebut.

d. Memperoleh seperangkat nilai, etika dan menjadikannya prinsip hidup Banyak nilai luhur yang ingin ditanamkan penyusun buku pada peserta didik. Nilai yang paling banyak ditampilkan adalah nilai keadilan, tabayun, tanggung jawab, dan bijaksana. Seperti pada kutipan bagian hikmah disyariatkannya perceraian adalah merupakan jalan penyelesaian terakhir dalam menghadapi kesulitan dan problem yang menimpa suami istri. Hukum thalaq adakalanya wajib, adakalanya haram, adakalanya sunnah, dan adakalanya mubah. Perceraian sebagai renungan bagi pemuda dan pemudi yang akan menikah untuk mencari pasangan dengan baik, bagi yang sudah menikah namun harus melewati tahap ini, diharapkan dengan cerai akan menemukan pasangan yang lebih baik dan sesuai dengan yang diharapkan.

e. Mempersiapkan pernikahan dan hidup berkeluarga

Salah satu sebab tingginya angka perceraian adalah kurangnya pemahaman dari laki-laki dan perempuan tentang tujuan pernikahanan, yaitu mewujudkan keluarga yang Sakinah Mawaddah. Maka peserta didik dari awal perlu pemahaman yang benar tentang konsep pernikahan yang sesuai dengan acara 
Islam. Antara laki-laki dan perempuan harus saling memahami peran dan berbagi tugas sesuai dengan porinya masing-masing

7. Kesesuaian Bab VII Hukum Waris dan Wasiat dengan Tugas Perkembangan

a. Beriman dan bertaqwa kepada Tuhan Yang Maha Esa

Keimanan peserta didik dapat ditingkatkan pada bab ini dengan cara menyadarkan mereka mengenai hikmah dibalik diaturnya masalah waris dalam Islam. Pada halaman 148-149, dijelaskan bahwa Allah mensyariatkan mawaris pada manusia agar manusia tidak bersengketa dalam urusan harta dan agar keadilan dalam pembagian harta waris dapat tercapai. Telah banyak terjadi kasus-kasus rusaknya keharmonisan keluarga diakibatkan oleh masalah pembagian harta waris. Perebutan harta waris antar saudara kandung seringkali membuat hancurnya hubungan kekeluargaan. Oleh karena itu, remaja yang telah memahami masalah mawaris, diharapkan dapat menerapkan pembagian waris saat mereka berkeluarga kelak

b. Memperoleh seperangkat nilai, etika dan menjadikannya prinsip hidup Nilai yang dapat diperoleh siswa pada bab ini adalah seperti yang tercantum pada halaman 151. Nilai tersebut yaitu bahwa kita harus berkarya untuk kebaikan bukan untuk menuruti hawa nafsu dan bercita-citalah menjadi kaya agar bisa membantu orang lain. Pada halaman 154 juga terdapat pernyataan bahwa hukum waris dalam Islam menunjukkan bahwa Islam menghormati hak milik orang lain dan menganut prinsip keadilan serta kepedulian

c. Memilih dan mempersiapkan karir

Dalam renungan kehidupan pada halaman 154, terdapat sebuah pelajaran yang sangat berharga yang dapat menuntut remaja untuk lebih mempersiapkan masa depan mereka termasuk dalam urusan karir. Berikut adalah pernyataan yang sesuai dengan tugas perkembangan memilih dan mempersiapkan karir, "Berkaryalah sesuai hati nurani dan jangan mengikuti hawa nafsu. Hiasilah perjalanan dan karya kalian dengan kebaikan lalu cobalah merumuskan langkah perjalanan menuju cita-cita yang diinginkan". Dari keterangan yang bersifat memotivasi tersebut, remaja yang masih merasa bingung dengan jalan karir yang akan dipilihnya, akan memperoleh prinsip dalam memilih karir yang akan digelutinya. Mereka harus mendengarkan hati nurani mereka dan memilih karir yang paling banyak membawa kebaikan bagi dirinya dan orang lain. Dalam usaha mencapai karir yang diinginkan, mereka juga harus merumuskan rencana sematang mungkin.

D. Hasil Analisis Kesesuaian Materi buku teks mata pelajaran Fikih Kelas XI Kurikulum 2013 dengan Kebutuhan Tugas Perkembangan Aspek Afektif

Setelah peneliti melakukan analisis terhadap setiap bab pada buku tersebut untuk menemukan kesesuaiannya dengan tugas pada aspek afektif adalah sebagai berikut:

\begin{tabular}{|l|l|l|l|l|l|l|l|}
\hline $\begin{array}{l}\text { Tugas Perkembangan / Bab } \\
\text { dalam Buku Teks }\end{array}$ & BAB I & BAB II BAB III & BAB IV & BAB V BAB VI & BAB VII \\
\hline $\begin{array}{l}\text { Mencapai hubungan yang lebih } \\
\text { matang dengan teman sebaya }\end{array}$ & & & & & & & \\
\hline Mencapai peran sosial sebagai & & & & $\sqrt{ }$ & $\sqrt{ }$ & $\sqrt{ }$ & \\
\hline
\end{tabular}




\begin{tabular}{|l|l|l|l|l|l|l|l|}
\hline pria atau wanita & & & & & & & \\
\hline $\begin{array}{l}\text { Mencapai kemandirian } \\
\text { emosional dari orang tua dan } \\
\text { orang dewasa lainnya }\end{array}$ & & & & & $\sqrt{ }$ & & \\
\hline $\begin{array}{l}\text { Mencapai jaminan kemandirian } \\
\text { ekonomi }\end{array}$ & & & & & $\sqrt{ }$ & & \\
\hline $\begin{array}{l}\text { Memilih dan mempersiapkan } \\
\text { karir }\end{array}$ & & & & & & & $\sqrt{ }$ \\
\hline $\begin{array}{l}\text { Mempersiapkan pernikahan } \\
\text { dan hidup berkeluarga }\end{array}$ & & $\sqrt{ }$ & & & $\sqrt{ }$ & $\sqrt{ }$ & \\
\hline $\begin{array}{l}\text { Mencapai tingkah laku yang } \\
\text { bertanggung jawab secara } \\
\text { sosial }\end{array}$ & $\sqrt{ }$ & & $\sqrt{ }$ & & $\sqrt{ }$ & $\sqrt{ }$ & \\
\hline $\begin{array}{l}\text { Memperoleh seperangkat nilai, } \\
\text { etika dan menjadikannya } \\
\text { prinsip hidup }\end{array}$ & $\sqrt{ }$ & $\sqrt{ }$ & $\sqrt{ }$ & $\sqrt{ }$ & $\sqrt{ }$ & $\sqrt{ }$ & $\sqrt{ }$ \\
\hline $\begin{array}{l}\text { Beriman dan bertaqwa kepada } \\
\text { Tuhan Yang Maha Esa }\end{array}$ & $\sqrt{ }$ & $\sqrt{ }$ & $\sqrt{ }$ & $\sqrt{ }$ & $\sqrt{ }$ & $\sqrt{ }$ & $\sqrt{ }$ \\
\hline
\end{tabular}

Dari data di atas bahwa jika dilihat dari jumlah bab yang sesuai pada masing-masing tugas perkembangan, maka hasil analisisnya adalah sebagai berikut.

1. Semua bab pada buku tersebut sesuai dengan tugas perkembangan siswa yang pertama yaitu beriman dan bertaqwa kepada Tuhan Yang Maha Esa dan tugas terakhir yaitu tugas memperoleh seperangkat nilai, etika, dan menjadikannya prinsip. Itu berarti tugas ini sangat diprioritaskan oleh penyusun materi buku ini.

2. Untuk tugas perkembangan yang kedua yaitu Mencapai tingkah laku yang bertanggung jawab secara sosial, ada empat bab yang sesuai yaitu bab I, bab III, bab $\mathrm{V}$ dan bab VI. Itu berarti ada tiga bab yang tidak sesuai dengan tugas perkembangan ini. Itu artinya, tugas perkembangan ini mendapat perhatian besar dari para penyusun materi fikih kelas XI.

3. Pada poin tugas perkembangan yang ketiga yaitu mencapai peran sosial sebagai pria atau wanita, ada tiga bab yang sesuai yaitu bab IV, bab V,dan bab VI. Ini berarti ada empat bab yang tidak mendukung ketercapaian peserta didik dalam mencapai tugas ini

4. Untuk poin tugas perkembangan yang keempat yaitu mencapai kemandirian emosional dari orang dewasa hanya ada satu bab yang sesuai, yaitu bab V. Dapat diartikan bahwa tugas ini, tidak begitu diperhatikan dalam penyusunan materi pada buku ini. Karena hanya satu dari sebelas bab yang sesuai dan artinya ada sepuluh bab yang tidak sesuai atau tidak mendukung ketercapaian peserta didik dalam mencapai tugas ini.

5. Sama halnya dengan tugas perkembangan yang kelima yaitu mencapai jaminan kemandirian ekonomi, hanya ada satu bab yang sesuai yaitu bab V saja. Jumlah yang sangat sedikit mengingat ada total tujuh bab pada buku. Itu artinya ada enam bab yang tidak sesuai dengan tugas ini. 
JCI

Jurnal Cakrawala IImiah

Vol.1, No.3, November 2021

6. Untuk tugas yang keenam yaitu memilih dan mempersiapkan karir, hanya ada satu bab yang sesuai dengan tugas tersebut yaitu bab VII. Sedangkan yang tidak sesuai, ada delapan bab. Jumlah ini sama dengan jumlah bab yang sesuai dengan tugas kedua dan keempat yaitu tugas mencapai kematangan hubungan dengan teman sebaya dan tugas mencapai kemandirian emosional dari orang dewasa.

7. Untuk tugas ketujuh atau tugas mempersiapkan pernikahan dan hidup berkeluarga, hanya ada tiga bab yang sesuai, yaitu bab II, bab V, dan bab VI. Sedangkan sisanya yaitu empat bab tidak sesuai sama sekali. Porsi yang sama dengan tugas perkembangan yang ketiga yaitu mencapai peran sosial sebagai pria atau wanita.

8. Meskipun ada satu tugas perkembangan yang tidak mendapat porsi sama sekali, atau mendapat porsi yang sangat minim dan tidak begitu diperhatikan pencapaiannya dalam penyusunan materi pada buku yang telah peneliti analisis, namun ketujuh bab yang ada pada buku tersebut, secara garis besar telah memuat semua tugas perkembangan dengan porsinya masing-masing. Oleh karena itu, materi pada buku yang peneliti analisis, dapat dikatakan sesuai dengan tugas perkembangan siswa pada aspek afektif.

Peneliti dapat mengelompokkan tugas-tugas tersebut berdasarkan porsi atau kuantitas kesesuaiannya dengan materi yang ada pada buku tersebut menjadi tiga kategori yaitu: kategori tinggi, sedang, dan rendah. Dengan rincian sebagai berikut

a. Kategori tinggi yaitu tugas-tugas perkembangan yang mendapat porsi kesesuaiannya paling banyak atau di atas 70\% sampai $100 \%$ dari jumlah bab keseluruhan. Tugas perkembangan yang masuk pada kategori ini, berarti sangat diperhatikan oleh para penyusun materi pendidikan pada mapel fikih kelas XI. Tugas-tugas yang masuk pada kategori ini ada tiga yaitu tugas beriman dan bertaqwa kepada Tuhan Yang Maha Esa, tugas memperoleh seperangkat nilai, etika, dan menjadikannya prinsip serta tugas mencapai tingkah laku yang bertanggung jawab secara sosial.

b. Kategori sedang yaitu tugas-tugas perkembangan yang mendapat porsi kesesuaian $30 \%$ sampai $60 \%$ dari jumlah bab keseluruhan. Tugas-tugas yang masuk pada kategori ini ada dua yaitu tugas mempersiapkan pernikahan dan hidup berkeluarga, dan Mencapai peran sosial sebagai pria atau wanita.

c. Kategori rendah yaitu tugas-tugas perkembangan yang mendapat porsi kesesuaian paling sedikit yaitu kurang dari 30\% dari jumlah bab keseluruhan. Tugas yang masuk kategori ini, berarti mendapat perhatian yang sangat kecil atau bahkan tidak sama sekali oleh penyusun materi fikih kelas XI. Ada empat tugas yang masuk pada kategori ini yaitu tugas mencapai hubungan yang lebih matang dengan teman sebaya, tugas mencapai kemandirian emosional dari orang tua dan orang dewasa lainnya, tugas mencapai jaminan kemandirian ekonomi, dan tugas memilih dan mempersiapkan karir.

Sedangkan pengelompoan bab atau materi pada buku tersebut berdasarkan porsi atau kuantitas kesesuaiannya dengan tugas-tugas perkembangan pada aspek afektif. Terdapat tiga kategori pengelompokan yaitu: kategori tinggi, sedang, dan rendah. Dengan rincian sebagai berikut.

a. Kategori tinggi yaitu bab atau materi yang paling banyak kesesuaiannya dengan tugastugas perkembangan, kurang lebih $70 \%$ sampai $100 \%$ dari jumlah tugas perkembangan secara keseluruhan. Bab atau materi yang masuk pada kategori ini, berarti sangat 
sesuai dengan tugas-tugas perkembangan afektif peserta didik yang duduk di bangku kelas XI. Materi atau bab yang masuk pada kategori ini berarti sesuai dengan minimal lima tugas perkembangan dari sembilan tugas. Materi tersebut yaitu bab kelima dan bab keenam

b. Kategori sedang yaitu bab atau materi yang kesesuaiannya dengan tugas-tugas perkembangan tergolong menengah. Tidak tinggi dan tidak rendah, kurang lebih $30 \%$ sampai $60 \%$ dari jumlah tugas perkembangan secara keseluruhan. Materi atau bab yang masuk pada kategori ini berarti sesuai dengan tiga sampai empat tugas perkembangan dari sembilan tugas yang ada. Materi tersebut yaitu bab pertama, bab kedua, bab ketiga, bab keempat, dan bab ketujuh

c. Kategori rendah yaitu bab atau materi yang kesesuaiannya dengan tugas-tugas perkembangan tergolong rendah, kurang dari 30\% dari jumlah tugas perkembangan secara keseluruhan. Materi atau bab yang masuk pada kategori berarti dikatakan sesuai dengan tingkat kesesuaian rendah karena hanya materi tersebut hanya sesuai dengan satu atau dua tugas saja dari total sembilan tugas yang ada. Untuk kategori rendah tidak ada dalam buku teks ini.

\section{KESIMPULAN}

Setelah melakukan analisis mengenai kesesuaian materi fikih kelas XI kurikulum 2013 terbitan Direktorat Jenderal Pendidikan Islam Kementerian Agama RI dengan kebutuhan tugas perkembangan siswa, dapat disimpulkan bahwa:

1. Sesuai amanat kurikulum 2013, buku teks fikih kelas XI ini dirancang untuk mengembangkan kompetensi yang utuh antara pengetahuan, keterampilan, dan sikap. Pembelajaran dalam buku ini dibagi dalam kegiatan-kegiatan keagamaan yang harus dilakukan peserta didik dalam usaha memahami pengetahuan agamanya dan diharapkan dapat berujung pada penerapan pemahaman tersebut dalam keseharian peserta didik.

2. Jika dilihat dari jumlah tugas perkembangan yang sesuai pada masing-masing bab, maka ada dua bab yang sangat sesuai dengan tugas-tugas perkembangan afektif yaitu bab kelima dan keenam. Sebaliknya, materi atau bab yang kurang sesuai atau sedang dengan tugas-tugas perkembangan, ada lima bab yaitu pertama, kedua, ketiga, keempat, dan ketujuh.

3. Jika dilihat dari jumlah bab yang sesuai pada masing-masing tugas perkembangan, terdapat tiga tugas yang sangat tinggi kesesuaiannya dengan materi, yaitu tugas beriman dan bertakwa pada Tuhan, tugas memperoleh seperangkat nilai, etika, dan menjadikannya prinsip, serta tugas mencapai tingkah laku yang bertanggung jawab secara sosial. Sedangkan, tugas yang tergolong rendah kesesuaiannya dengan materi yang tersaji pada buku, ada empat juga yaitu tugas mencapai peran sosial sebagai pria atau wanita, tugas mencapai jaminan kemandirian tugas mencapai hubungan yang lebih matang dengan teman sebaya, tugas mencapai kemandirian emosional dari orang tua dan orang dewasa lainnya, tugas mencapai jaminan kemandirian ekonomi, dan tugas memilih dan mempersiapkan karir. Sedangkan tugas lainnya, masuk kategori sedang

\section{SARAN}

Saran Berdasarkan kesimpulan hasil analisis, maka penulis berpendapat bahwa 
JCI

Jurnal Cakrawala IImiah

Vol.1, No.3, November 2021

seharusnya materi yang kurang sesuai dengan tugas-tugas perkembangan afektif yaitu materi tentang menghidupkan nurani dengan berpikir kritis, lebih diperkaya lagi dengan pembahasan-pembahasan yang menunjang ketercapaian tugas perkembangan afektif. Meskipun aspek koginitf memang lebih ditekankan pada bab tersebut. Namun, antara kognitif dan afektif pada dasarnya saling berkaitan dan harus disajikan secara berimbang. Materi tersebut sebenarnya berpeluang besar untuk bisa dikaitkan dengan tugas memilih dan mempersiapkan karir, bertanggung jawab secara sosial, mencapai kematangan hubungan dengan teman sebaya dan tugas-tugas lainnya. Namun pada buku tersebut, materi mengenai berpikir kritis, hanya dikaitkan dengan fenomena alam dan rasa syukur. Sedangkan berpikir kritis dalam menyikapi keadaan sosial sama sekali tidak disinggung.

Keempat tugas yang kurang diperhatikan dalam penyusunan buku tersebut, yaitu tugas mencapai hubungan yang lebih matang dengan teman sebaya, tugas mencapai kemandirian emosional dari orang tua dan orang dewasa lainnya, tugas mencapai jaminan kemandirian ekonomi, dan tugas memilih dan mempersiapkan karir, seharusnya lebih disesuaikan lagi dengan tugas perkembangan afektif. Caranya yaitu dengan menambahkan materi baru dalam bentuk satu bab utuh atau memperkaya materi pada pada bab yang sudah ada

\section{DAFTAR PUSTAKA}

[1] Ahmad, Abdul Kadir \& Rahayu, Kun Mardiwati, 2020, Integrasi Kurikulum 2013 dan Kurikulum Al Azhar Asy Syarif di MTsN Al Azhar Asy Syarif Indonesia, Jurnal Pendidikan Guru, Vol. 1, No. 3, Juli 2020, hlm. 151-162

[2] Ahmadi, 2013, Manajemen Kurikulum: Pendidikan Kecakapan Hidup, Pustaka Ifada, Yogyakarta.

[3] Arifin, Muzayyin. 2011, Kapita Selekta Pendidikan Islam, Bumi Aksara, Jakarta.

[4] Handayani, Rina Asih. 2015, "Analisis Kesesuaian Antara Materi dengan Kompetensi Inti dan Kompetensi Dasar Kurikulum 2013," (Tesis, UIN Sunan Kalijaga, Yogyakarta

[5] Jannah, Miftahul. 2016, "Remaja dan Tugas-Tugas Perkembangannya dalam Islam," Psikoislamedia, Vol. 1 No.1

[6] Prahara, Erwin Y. 2009, Materi Pendidikan Agama Islam, STAIN Po Press, Ponorogo.

[7] Prastowo, Andi. 2015, Pembelajaran Konstruktivisttik-Scientific untuk Pendidikan Agama di Sekolah/Madrasah, Raja Grafindo Persada, Jakarta.

[8] Sarwono, Sarlito W. 2011, Psikologi Remaja, Raja Grafindo Persada, Jakarta

[9] Sugiyono, 2015, Metode Penelitian Pendidikan Pendekatan Kuantitatif, Kualitatif, dan R\&D, Alfabeta, Bandung

[10] Tohirin, 2005, Psikologi Pembelajaran Pendidikan Agama Islam, Raja Grafindo Persada, Jakarta.

[11] Yusuf, Syamsu. 2012, Buku Psikologi Perkembangan Anak dan Remaja, Remaja Rosdakarya, Bandung.

[12] Zurqoni dan Mukhibat, 2013, Menggali Islam Membumikan Pendidikan, Ar-Ruzz Media, Jogyakarta. 